\title{
Cellular aspects of liver regeneration ${ }^{1}$
}

\author{
Aspectos celulares da regeneração hepática ${ }^{1}$
}

\author{
Marissa Rabelo Tarlá ${ }^{2}$, Fernando Ramalho ${ }^{3}$, Leandra Naira Zambelli Ramalho ${ }^{4}$, Tiago Castro e Silva ${ }^{5}$, Daniel Ferracioli \\ Brandão $^{2}$, Juliana Ferreira ${ }^{2}$, Orlando Castro e Silva ${ }^{6}$, Sérgio Zucoloto ${ }^{7}$
}

1. Study performed in the Laboratory of Cellular Proliferation of the Department of Pathology of the Faculty of Medicine of Ribeirão Preto, University of São Paulo, (FMRP-USP), Brazil.

2. Fellow PhD degree of the Department of Pathology, (FMRP-USP), Brazil.

3. PhD, Professor of the Department of Surgery and Anatomy, (FMRP-USP), Brazil

4. PhD, Professor of the Department of Pathology, (FMRP-USP), Brazil.

5. Graduate Student of the Physical Institute of São Carlos - University of São Paulo (IFSC-USP), Brazil.

6. Full Professor, Head of Division of Gastroenterology of the Department of Surgery and Anatomy, Coordinator of the Liver Transplant Program, (FMRP-USP), Brazil.

7. Full Professor of the Department of Pathology, (FMRP-USP), Brazil.

\begin{abstract}
This paper has the objective to analyze the cellular aspects of liver regeneration (LR). Upon damage in this organ, the regenerative capacity of hepatocyte is sufficiently able to reestablish the parenchyma as a whole. Taking into account the regenerative capacity of hepatocyte, the need of a progenitor or a liver trunk cell was not obvious. Nowadays it is wellestablished that precursor cells take part in the liver regenerative process. The liver trunk cell, oval cell, acts as a bypotential precursor, contributing for the liver restoration, mainly when the hepatocytes are unable to proliferate. Another precursor, trunk cell of hematopoetic origin (HSC), takes part in the regenerative process, originating cells of the hepatocitic lineage and colangiocytes, as well as the oval cell. The way the trans-differentiation takes place is not established yet. A number of studies must be undertaken in order to clarify questions, such as the possible occurrence of cellular fusion process between the HSC and the hepatic cells and the possibility of application as a new therapeutic procedure in the treatment of diseases associated with insufficiency of this noble organ.
\end{abstract}

Key words: Liver Regeneration. Oval Cell. Liver. Trunk Cells.

\section{RESUMO}

Este artigo tem como objetivo analisar aspectos da regeneração hepática $(\mathrm{RH})$ sob a óptica celular. Em vigência de uma lesão neste órgão a capacidade regenerativa do hepatócito é suficientemente capaz de restabelecer o parênquima como um todo. Levando em conta a elevada capacidade regenerativa do hepatócito, a necessidade de um progenitor ou uma célula tronco hepática não era óbvia. Hoje esta bem estabelecido que células precursoras participam do processo regenerativo hepático. A célula tronco hepática, célula oval, atua como um precursor bipotencial, contribuindo para o restauro do fígado principalmente quando os hepatócitos se encontram impossibilitados de proliferar. Um outro precursor, a célula tronco de origem hematopoética (HSC), participa do processo regenerativo, originando células da linhagem hepatocítica e colangiócitos, assim como a células oval. Ainda não está estabelecido o meio como ocorre o fenômeno de transdiferenciação.Muitos estudos devem ser realizados no intuito de esclarecer questões, tais como a possível ocorrência de processo de fusão celular entre a HSC e as células hepáticas e a possibilidade de ser aplicado como uma nova terapêutica no tratamento de doenças associadas à insuficiência deste nobre órgão.

Descritores: Regeneração Hepática. Célula Oval. Fígado. Células Tronco.

\section{Introduction}

The liver is one of the most complex organs of the human body. Mammals keep a constancy of liver mass throughout their lives; in order to occur this permanency there is the need of maintenance of this tissue. Aspects of liver regeneration have been described since long in the history of mankind, tracing back to reports of the Greek mythology, such as the story of Chained Prometeu that is one of the classical plays of the Greek tragedy written by Esquilo in 470 a.d., where an eagle used to daily devour his liver, which could reconstitute itself. Experimental models have been developed to study this fascinating regenerative aspect; the most used experience was developed by Higgins and Anderson in 1931. ${ }^{1}$ It consists of a partial hepatectomy of two thirds of the liver with removal of the two frontal lobes, which comprise about $70 \%$ of the liver tissue. Partial hepatectomy has the advantage of inducing a regenerative response without occurrence of damage in the 
remanescent tissue, which differs from harmful processes caused by toxic or viral agents, cancer or cirrhosis, where the hepatocyte regenerative capacity is impaired. In cases where the hepatocyte proliferation capacity is inhibited, cells that able to differentiate into liver tissue come into action such as trunk cells of the liver itself, oval cells, and extra hepatic trunk cells, such as trunk cells of hematopoetic origin. In addition to these cellular mechanisms, a series of genes, cytokines and growing factors are involved in the regenerative process. The exact mechanism of regeneration and interaction between cells and cytokines is not entirely clarified yet. We have noted a sequence of orchestrated events that results in the regeneration of this organ. The elucidation of these processes should provide a better management of cases of terminal liver disease; particularly by the induction of the liver regenerative process.

\section{Hepatocytes}

The liver is one of the most complex organs of the human body. Due to the high degree of differentiation, the hepatocyte is a cell that rarely divides. However, its replication capacity is not lost. Despite this slow cell turn-over, hepatocytes and colangiocites show a marked capacity to supply the cellular demands when there is tissue damage. ${ }^{2}$ In animal models, DNA synthesis starts within 12 to 16 hours after the partial hepatectomy process ( $\mathrm{PH})$, with a peak around 24 to 48 hours. Three days after a $\mathrm{PH}$, there is restoration of the liver mass, but in this stage of the liver regeneration, the histology is very different from a normal liver tissue. The hepatocytes are grouped into non-vascularized clusters with about 12 to 15 cells. The extra cellular matrix is reduced due to the hepatocyte expansion without the synthesis of a new matrix. Following this period, hepatocyte proliferation decreases and starred cells migrate to the clusters, at the same time, new vases are made up. The histology and the liver function reestablish around 8 to 10 days after surgery. ${ }^{3}$ In addition to this regenerative ability proper to the organ, it has also been noted that transplanted cells are capable of marked clonal expansion in injured livers, both in animals and in human beings. Liver progenitor cells, with pluri-potential features, abundant in fetal liver, might be used for liver transplantation For instance, fetal liver progenitor cells that do not express the greater complex of histocompatibility class I (MHCI), may escape from the immunological system when they are transplanted even in incompatible MHC recipients. ${ }^{4}$ DPPIV animals, subjected to the administration of Retrosine, drug that causes liver damage, showed liver colonization with 60 to $80 \%$ of DPPIV positive hepatocytes, within six months after transplantation. ${ }^{5}$ Colonogenic cells may be isolated from the fetal liver of rats. Hepatocytes expressing integrine a6 (CD49f) and B1 (CB29), but not c-Kit, CD45 or Ter 119 (eritróide precursor antigen), show a great ability to make up cultures. Then these precursors were termed forming units of liver colonies in cultures $(\mathrm{H}-$ CFU-C), when selected by the_expression c-met, were able to produce hepatocytes (positive albumine) and colangiocytes (CK 19 positive) in culture. Marked EGFP cells, clonally derived from H-CFU-C, produced hepatocytes and cells of the biliar tract when they injected into rats. Surprisingly, it as also found differentiation in ducts and pancreatic acids, as well as in cells of the duodenal mucosa when they were directly injected into these organs, suggesting the presence of a unique pluri-potent precursor. ${ }^{6}$ Even the transplantation of hepatocytes that have already differentiated, non-fetal, has turned out to be effective in the normalization of bilirrubine livels and in the implementation of the activity to conjungate bilirrubine in Gunn rats (a modelo of syndrome of Crigler-Najjar). Infusion of hepatocytes through the port vein, equivalent to $5 \%$ of the parenchimatous mass in patients with syndrome of Crigler Najjar, may result in reduction of sreum levels of billirubines and the increase of bilirrubine conjugated in the bile. ${ }^{7}$ Hepatocyte transplantation has shown success in the treatment of diseases of storage of glicogenio type Ia. ${ }^{8}$

\section{Liver Oval Cells}

The concept of stem cell was established from the epithelium of the gastrointestinal and cutaneous tracts, where progenitor cells (stem) differentiate irreversibly towards the final specialization stages. This process is associated with the gradual loss of the proliferating ability of the specialized cells. ${ }^{9}$ Liver stem cells were first postulated by Kinosita in 1937, but their identification was actually established in experiments about hepatocarcinogenesis using 2-acetilaminofluorene (2AAF), which impairs the proliferation of hepatocytes and dietilnitrosamine (DEN), a powerful cancer agent. Then they were called "oval cells" owing to its morphological aspect, with scarce cytoplasm and ovóide nucleus. ${ }^{10}$ Oval cell proliferation can be noted by means of the exposition of the animal to 2-AAF and the induction of liver damage, such as a hepatectomy, but without the use of DEN. ${ }^{11}$ Oval cells were considered as an undifferentiated cell group able to reestablish the liver tissue, intestinal epithelium and pancreas. ${ }^{12}$ They can originate from cells present in the Hering's duct or from undifferentiated cells near to the biliar ducts. They constitute a narrow bando of cells adjacent to the Hering's canals, anatomic junction of the canalicular system, or in terminal branches of the biliar tree. ${ }^{13}$ They may both be a precursor source and have a supportive or inductive role. Oval cell population is heterogenous and constitute a sub-population of epithelial cells showing a potential for diverse development, depending on the degree of impairment of the specific lineage. However, there is still not an accurate definition of the factors associated with the in vivo differentiation of oval cells in hepatocytes. Notwithstanding, when the liver tissue is subjected to na aggresion, in which hepatocytes are unable to proliferate, this optional compartment of oval cells may be activated, thus regenerating the liver tissue. ${ }^{12,13}$ Similar to the rest of stem cells of adult tissues, oval cells show a common cellular origin (clonal), ability for self-renovation, proliferative potential, differentiation, capacity to regenerate tissues after injury, presence of markers of specific lineage and cellular undifferentiation. ${ }^{14}$ Antigens that are traditionally associated with hematopoetic stem cells may be expressed in oval cells, including c-Kit, flt-3, Thy-1 e CD34. ${ }^{15}$

\section{Hematopoetic stem cells}

It was observed that in experimental model of alcoholinduced peri-portal necrosis there was the appearance of "null" proliferative cells, negative both for hepatocyte markers and for colangiocyte markers. It is possible that all cells of undifferentiated phenotype or "null" cells derive from cells of 
the Hering's canal or of the biliar ducts, and have lost the expression of colangiocyte markers in the early stages of proliferation, configurating the undifferentiation stage. This narrow band of cells adjacent to the Hering's canals or in terminal branches of the biliar tree would not be the source of these cells. ${ }^{16}$ The demonstration of transformation of cells from the osseous medulla of the damaged skeleton muscle, suggested that cells derived from the osseous medulla may have the role of progenitor cells in tissues under aggression, as a possible transdifferentiation of these cells. ${ }^{17}$ Recent studies support evidence that adult stem cells, particularly the hepatopoetic ones, may graft diverse sites, particularly when they are damaged. These cells may expand clonally, differentiate, making a contribution to the grafted tissue. Similarly, hematopoetic stem cells may be amplified in vitro and stimulated to differentiate in many types of tissues. Supportive evidence for the so-called plasticity of the stem cells is related to the demonstration of positive chromosome $\mathrm{Y}$ cells in a female receptor of osseous medulla transplantation from a male donor. These techniques are usually combined with markers of specific lineage of the tissues in an attempt to decide whether there has been an actual deviation (transdifferentiation) of transplanted cells. ${ }^{18}$ Peterson et al, $1999,{ }^{19}$ was the first to demonstrate the trans-differentiation of progenitor cells of hematopoetic origin in liver tissue in animal model. This hypothesis was studies in experimental model, in which there was osseous medulla transplantation in isogenic rats with gender discrepancy. It was concluded with this study that: cells from the osseous medulla would have an ability to transform into liver tissue through the colonization in the form o hepatocytes and colangiocytes like an oval cell, Transdifferentiation of hematopoetic stem cell in hepatocytes has been widely investigated. It was possible to observe that the liver colonization by cells from the donor had already been detected in differentiated form in hepatocytes and colangiocytes through transplantation of male Fah positive donors in female Fah negative recipients, with the graft result around $30 \%$ of the hepatocytes. ${ }^{20}$ Melted cells were found by using the same protocol, added to the cariotypic analysis of the grafted cells; Fah positive cells mixed with the recipient's cells. ${ }^{21}$ Since then, the plasticity of adult stem cells has been questioned, suggesting transdifferentiation through the product of cellular fusion of non-melted stem cell and preexistent differentiated cells. Hepatic nodules, expressing FAH, were generated by the transplantation of osseous medulla of FAH + rats in irradiated females FAH (-). The analysis of chromosome in metaphase revealed that hepatocytes derived form donor showed normal cariotypes (40 XY), tetraplodia ( 80 XXXY) or hexaploidia (120XXXXXXYY), suggesting the fusion and not the differentiation of hematopoetic stem cells. ${ }^{21,22}$ It is still incertain what is exactly the cell type that fuses with the recipient's liver. It was early presumed that they were the hematopoetic stem cells derived from the donor fused with the recipient's tissues. It was suggested that even macrophages (Kuppfer's cells) may fuse with other cells. In response to the injury, myeloid precursor cells might be recruited as part of the inflammatory response and incorporate to the liver parenchyma in a fusion form. ${ }^{23}$ On the other side, the fusion phenomenon was not observed in transdifferentiation model of hematopoetic cells of cordão in hepatocytes. ${ }^{24}$ Human studies have shown that the cellular fusion hás little or no role in cellular transdifferentiation process. ${ }^{23}$ There is a variety of mechanisms that are responsible for the genomic plasticity. Cellular fusion may occur in certain systems, and transdifferentiation without fusion may take place in others. So far, factors that regulate these occurences remain uncertain. A possible demonstration of the therapeutic potential of hematopoetic-origin cell transdifferentiation was proposed: female mice, defficient for enzyme hydroxylase fumarilacetate (fash -/-), a model of tirosenemia type I hereditary), were transplanted with osseous medulla of male mice Fah+, giving a positive result with a colonization around 30 to $50 \%$ of cells presenting positives SRY and Fah, from the donor, reestablishing the liver metabolic function of the mice that received osseous medulla. ${ }^{25}$ Due to the possibility of transdifferentiation occurence of progenitors of hematopoetic cells in liver tissue, several questions have been raised by a few researchers about the origin of oval cells from these progenitors of osseous medulla. ${ }^{19,26}$ Other studies suggest that cells originated from the medulla are distintic cell groups of oval cells, as a third storage supply for the liver regeneration. ${ }^{15,27,28}$ In transplantation model of osseous medulla in rats, it has been demonstrated that epithelial chromossome Y positive cells with co-_expression CK 19 would be extrahepatic circulating stem cell, which had colonized the liver and acquired phetotype similar to that of the oval cells. ${ }^{26}$ Studies of hepatic stem cell markers showed that hepatic/hematopoetic stem cells could be negative for Thy-1 and CK19, but positive for other markers of undifferentiation such as c-kit and CD34, and the oval cells would be positive for CK-19 and could show variations (positive or negative) concerning their marking for c-kit, Thy-1 and CD34. ${ }^{26}$ Using double immuno-histochemical marking, it was demonstrated that morphologically oval cells expressed a marking that is typical to oval cells, CK19 positive, but DDP4 negative, and it was concluded that the progenitors that had colonized the liver did not transdifferentiate in oval cells. $^{28}$ These findings show substantial evidence that oval cells in the liver of roedents may be considered a specific progenitor of liver stem cells, and not a progeny from hematopoetic stem cells.

\section{References}

1. Higgins G.M, Anderson R.M. Experimental pathology of the liver: Restoration of the liver of the white rat following partial surgical removal. Arch Pathol. 1931; 186:1935-41.

2. Sell S. Is there a liver stem cell. Cancer Research. 1990; 50:3811-15.

3. Fausto N. Liver regeneration. J Hepatol. 2000; 32:19-31.

4. .Kubota H, Reid L.M, Clonogenic hepatoblasts, common precursor for hepatocytic and biliary lineages, are lacking classic major histocompatibility complex class I antigen. Proc. Natl Acad. Sci. 2000; 97:12132-7.

5. Dabeva M.D, Petkov P.M, Sandhu J. Proliferation and differentiation of fetal liver epithelial progenitor cells after transplantation into adult rat liver. Am J Pathol. 2000; 156:2017-13.

6. Suzuki A, Zheng Y, Kaneko S, Onodera M, Fukao K, Nakauchi H. Clonal identification and characterization of self renewing pluripotente stem cells in the developing liver. J Cell Biol. 2002; 156:173-6. 
7. Fox IJ, Chowdhury JR, Kaufman SS, Goerten SS, Sauter BV. Treatment of Crigler- Najjar syndrome type I with hepatocytes transplantation. N Engl J Med. 1998; 338:1422-6.

8. Muraca M, Gerunda G, Neri D, Vilei MT, GranatoA, Feltracco O, Meroni M, Giron G, Burlina AB. Hepatocytes transplantation as a treatment for glycogen storage disease type 1a. Lancet. 2002;359:317-8.

9. Marceau N. Ephitelial cell lineages in developing, restoring and transforming liver: evidence for the existence of a "differentiation window". Gut. 1994; 35:294-6.

10. Farber E. Similarities in the sequence of early histological changes induced in the live of the rat by ethionone, 2acetylaminofluorene, and 3-methyl-4dimthylaminoazobenzene. Cancer Res. 1956; 16:142-8.

11. 11. Evarts RP, Nagy P, Nakatsukas H, Marsden E, Thogeirsson SS. In vivo differentiation of rat liver oval cells into hepatocytes. Cancer Res. 1989; 49:1541-7.

12. Thorgeirsson SS. Hepatic stem cell in liver regeneration. FASEB J. 1996; 10:1249-6.

13. Theise ND, Saxena R, Portmann BC, Thung SN, Yee $\mathrm{H}$. The canals of Hering and hepatic stem cells in humans. Hepatology. 1999; 30:1425-33.

14. Potten CS, Loffler M. Stem cells- attributes, cycles, spirals, pitfalls and uncertain. Development. 1990; 110:1001-20.

15. Sell S. Heterogeneity and plasticity of hepatocytes lineage cells. Hepatology. 2001; 33:738-50.

16. Yavorkovsky L, Lail L, Ilic Z, Sell S. Participation of small intraportal stem cells in the restitutive response of the liver to periportal necrosis induced by alcohol. Hepatology. 1995; 21: 1702-12.

17. Ferrari G, Cussella-De Angelis G, Colletta M, Paolucci E, Stornaiuolo A, Cossu G, Mavilio F. Muscle regeneration by bone marrow-derived myogenic progenitors. Science. 1998; 279:1528-30.

18. Alison MR, Poulsom R, Otto WR, Vig P, Brittan M, Direkze NC, Preston SL, Wright NA. Plastic adult stem cell: will they graduate from the school of hard knocks? J Cell Sci. 2003; 116:599-603.
19. Petersen BE, Bowen WC, Patrene KD, Mars WM, Sullivan AK, Murase N, Boggs SS, Greenberger JS, Goff JP. Bone marrow as a potential source of hepatic oval cells. Science. 1999; 284:1168-70.

20. Wang X, Foster M, Dhalimy MA, Lagasse E, Finegold M, Grompe $\mathrm{M}$. The origin and liver repopulating capacity of murine ovals cells. PNAS, 2003; 100:11881-88.

21. Wang X, Willenbring H, Akkari Y, Torimaru Y, Foster M, Lagasse E, Finegold M, Olson S, Grompe M. Cell fusion is the principal source of bone marrow derived hepatocytes. Nature. 2003; 422:897-900

22. Vassipoloulos G, Wang PR, Russell DW. Transplanted bone marrow regenerates liver by cell fusion. Nature. 2003; 442:901-904.

23. Masson S. Harrison DJ, Plevris JN, Newsome N. Potential of Hematopoietic Stem Cell Therapy in Hepatology: Acritical review. Stem Cell. 2004; 22:897-907

24. Newsome P, Johannessen I, Boyle S. Human cord blood derived cells can differentiate in the mouse liver with no evidence of cellular fusion. Gastroenterology. 2003; 124:1891-900.

25. Lagasse E, Connors H, Al-Dhalimy M, Reitsma M, Dohse M, Osborne L, Wang X, Finegold M, Weissman IL, Grompe M.. Purified hematopoetic stem cells can differentiate into hepatocytes in vivo. Nat Med. 2000; 6:1229-34.

26. Alison MR, Poulsom R, Jeffery R, Dhilon AP, Quaglia A, Jacob J, Novelli M, Prentice G, Willianson J, Wright NA. Hepatocytes from non-hepatic adult stem cells. Nature. 2000; 406: 257-64.

27. Crosby HA, Nijjar SS. Goyet JV, Kelly DA, Strain AJ. Progenitor cells of the biliary epithelial cell lineage. Semin Cell Dev Biol. 2002; 13:397-403.

28. Menthena A, Deb N, Oertel M, Grozdanov PN, Sandhu J, Shan S, Guha C, Shafritz DA, Dabeva MD. Bone marrow progenitors are not the source of expanding oval cells in injured liver. Stem Cells. 2004; 22:1049-61.

\section{Correspondence:}

Orlando de Castro e Silva Jr.

Rua Campos Salles, 809 - $9^{\circ}$ andar. CEP: 14015-110

Centro, Ribeirão Preto - SP - Brazil.

Email: orlando@,fmrp.usp.br

\section{How to cite this article:}

Tarlá MR, Ramalho FS, Ramalho LNZ, Castro-e-Silva T, Brandão DF, Ferreira J, Castro e Silva O, Zucoloto S. Cellular aspects of liver regeneration. Acta Cir Bras [serial on the Internet] 2006;21 Suppl. 1. Available in www.scielo.br/acb 